Supporting Information for

\title{
Hydrothermal Synthesis of Delafossite-type Oxides
}

William C. Sheets, Emmanuelle Mugnier, Antoine Barnabe, Tobin J. Marks, and Kenneth R. Poeppelmeier

Department of Chemistry, Northwestern University, Evanston, IL 60208-3113. 
Materials. The B-site cation sesquioxides, oxide hydroxides or trihydroxides are obtained from commercial sources or prepared from literature sources.

$\boldsymbol{\alpha}-\mathrm{Al}_{2} \mathbf{O}_{3}$. Aldrich, $99.9 \%$. The $\alpha-\mathrm{Al}_{2} \mathrm{O}_{3}$ was heated at $850{ }^{\circ} \mathrm{C}$ for 12 hours prior to the reaction.

$\boldsymbol{\gamma}$-Al(OH $)_{3 .}{ }^{1}$ Crystalline $\mathrm{Al}(\mathrm{OH})_{3}$ was prepared by precipitation of a $1 \mathrm{M} \mathrm{Al}^{3+}$ aqueous solution with an approximately $5 \mathrm{M} \mathrm{NH} \mathrm{NH}_{4}$ aqueous solution. The aqueous $\mathrm{Al}^{3+}$ solution was prepared from $\mathrm{Al}\left(\mathrm{NO}_{3}\right)_{3} \cdot 9 \mathrm{H}_{2} \mathrm{O}$ (Aldrich, 98+\%). The addition was done drop-wise under stirring. Base was added until the solution was basic $(\mathrm{pH}>10)$ as measured by $\mathrm{pH}$ paper. The precipitate was the allowed to age for $48 \mathrm{~h}$ in the mother liquor, isolated by vacuum filtration, washed with deionized water several times, and allowed to dry in vacuo at ambient temperature.

-AlOOH. $^{1}$ First, amorphous $\mathrm{Al}(\mathrm{OH})_{3}$ was prepared by precipitation of a $1 \mathrm{M} \mathrm{Al}^{3+}$ aqueous solution with an approximately $5 \mathrm{M} \mathrm{NH}_{4} \mathrm{OH}$ aqueous solution. The aqueous $\mathrm{Al}^{3+}$ solution was prepared from $\mathrm{Al}\left(\mathrm{NO}_{3}\right)_{3} \cdot 9 \mathrm{H}_{2} \mathrm{O}$ (Aldrich, 98+ \%). The addition was done drop-wise under stirring. Base was added until the solution was basic $(\mathrm{pH}>10)$ as measured by $\mathrm{pH}$ paper. The precipitate and the mother liquor, were transferred to a $45 \mathrm{~mL}$ Teflon-lined Parr pressure vessel, which was then sealed and heated to $175^{\circ} \mathrm{C}$ for a minimum of 12 hours. The crystalline $\mathrm{AlOOH}$ was isolated by vacuum filtration, washed with deionized water several times, and allowed to dry in vacuo at ambient temperature.

$\mathbf{S c}_{2} \mathbf{O}_{3}$. Alfa Aesar, $99.99 \%$. The $\mathrm{Sc}_{2} \mathrm{O}_{3}$ was heated at $850{ }^{\circ} \mathrm{C}$ for 12 hours prior to the reaction.

$\mathrm{Sc}(\mathrm{OH})_{3}$. The aqueous $1 \mathrm{M} \mathrm{Sc}^{3+}$ solution was prepared by dissolution of $\mathrm{Sc}_{2} \mathrm{O}_{3}$ in a concentrated nitric acid solution maintained at $80{ }^{\circ} \mathrm{C}$. After cooling, amorphous $\mathrm{Sc}(\mathrm{OH})_{3}$ gel was prepared by precipitation of the cold (ice bath temperature) $1 \mathrm{M} \mathrm{Sc}^{3+}$ aqueous solution with excess $5 \mathrm{M} \mathrm{NH}_{4} \mathrm{OH}$. The amorphous $\mathrm{Sc}(\mathrm{OH})_{3}$ gel and mother liquor were then transferred to a pressure vessel $(125 \mathrm{~mL}$ Teflon-lined, Parr Instruments), which was then sealed and heated to $100{ }^{\circ} \mathrm{C}$ for a minimum of $12 \mathrm{~h}$. The crystalline $\mathrm{Sc}(\mathrm{OH})_{3}$ was isolated by vacuum filtration, washed with deionized water several times, and allowed to dry at $85^{\circ} \mathrm{C}$ in a drying oven for a minimum of $12 \mathrm{~h}$. 
$\mathbf{T i}_{2} \mathbf{O}_{3}$. Aldrich, $99.9 \%$. Stored in a nitrogen dry box.

$\mathbf{V}_{\mathbf{2}} \mathbf{O}_{3}$. Aldrich, $99.99 \%$. Stored in a nitrogen dry box.

$\mathrm{Cr}_{2} \mathbf{O}_{3}$. Aldrich, $99.995 \%$.

CrOOH. $^{2}$ CrOOH was prepared by precipitation of a cold (ice bath temperature) $0.1 \mathrm{M} \mathrm{Cr}^{3+}$ aqueous solution with an approximately $2 \mathrm{M} \mathrm{NH}_{4} \mathrm{OH}$ aqueous solution. The aqueous $\mathrm{Cr}^{3+}$ solution was prepared from $\mathrm{Cr}\left(\mathrm{NO}_{3}\right)_{3} \cdot 9 \mathrm{H}_{2} \mathrm{O}$ (Aldrich, $99 \%$ ). The addition was done drop-wise under stirring. Base was added until the solution was slightly basic as measured by $\mathrm{pH}$ paper. The precipitate was the allowed to age for $48 \mathrm{~h}$ in the mother liquor, isolated by vacuum filtration, washed with deionized water several times, and allowed to dry at $85^{\circ} \mathrm{C}$ in a drying oven for a minimum of $12 \mathrm{~h}$.

$\mathrm{Cr}(\mathrm{OH})_{3} \cdot 3 \mathrm{H}_{2} \mathrm{O}{ }^{2}$ Crystalline $\mathrm{Cr}(\mathrm{OH})_{3} \cdot 3 \mathrm{H}_{2} \mathrm{O}$ was prepared by precipitation of a cold (ice bath temperature) $0.1 \mathrm{M} \mathrm{Cr}^{3+}$ aqueous solution with an approximately $2 \mathrm{M} \mathrm{NH}_{4} \mathrm{OH}$ aqueous solution. The addition was done drop-wise under stirring. The aqueous $\mathrm{Cr}^{3+}$ solution was prepared from $\mathrm{Cr}\left(\mathrm{NO}_{3}\right)_{3} \cdot 9 \mathrm{H}_{2} \mathrm{O}$ (Aldrich, $99 \%$ ). Base was added until the solution was slightly basic as measured by $\mathrm{pH}$ paper. The precipitate was isolated by centrifuge, washed with deionized water several times, and allowed to dry in vacuo at ambient temperature.

$\mathbf{M n}_{2} \mathbf{O}_{3}$. Cerac, $99.99 \%$.

$\mathrm{Fe}_{2} \mathbf{O}_{3}$. Alfa Aesar, $99.99 \%$.

$\alpha$-FeOOH. ${ }^{3}$ Crystalline goethite was prepared by adding $100 \mathrm{~mL}$ of a $1 \mathrm{M} \mathrm{Fe}^{3+}$ aqueous solution into a $4 \mathrm{~L}$ polyethylene flask (to prevent some silicon dissolving from glass vessels), and rapidly adding with stirring, $180 \mathrm{~mL}$ of $5 \mathrm{M} \mathrm{KOH}$. The aqueous $\mathrm{Fe}^{3+}$ solution was prepared from $\mathrm{Fe}\left(\mathrm{NO}_{3}\right)_{3} \cdot 9 \mathrm{H}_{2} \mathrm{O}$ (Aldrich, $99 \%$ ). The mixed solution was immediately diluted to $2 \mathrm{~L}$ with distilled water and the polyethylene flask was sealed and placed in an oven at $70{ }^{\circ} \mathrm{C}$ for $60 \mathrm{~h}$. The yellow precipitate was isolated by 
vacuum filtration, washed with deionized water several times, and allowed to dry in vacuo at ambient temperature.

-FeOOH. $^{3}$ Crystalline lepidocrocite was prepared by bubbling air $(\sim 100 \mathrm{~mL} / \mathrm{min})$ for $3 \mathrm{~h}$ through a porous frit into $300 \mathrm{~mL}$ of $60 \mathrm{mmol} \mathrm{Fe}^{2+}$ aqueous solution. The aqueous $\mathrm{Fe}^{2+}$ solution was prepared from $\mathrm{FeCl}_{2} \cdot 4 \mathrm{H}_{2} \mathrm{O}$ (Aldrich, $99 \%$ ). The drop-wise addition of $120 \mathrm{~mL}$ of $1 \mathrm{M} \mathrm{NaOH}$ aqueous solution from a burette over the $3 \mathrm{~h}$ maintains the solution $\mathrm{pH}$ between $6.7-6.9$. The orange precipitate was isolated by vacuum filtration, washed with deionized water several times, and allowed to dry in vacuo at ambient temperature.

CoOOH. ${ }^{4}$ First, $\alpha-\mathrm{Co}(\mathrm{OH})_{2}$ was prepared by precipitation from a $1.0 \mathrm{M} \mathrm{Co}^{2+}$ aqueous solution with the addition of an approximately $2 \mathrm{M} \mathrm{NH}_{4} \mathrm{OH}$ aqueous solution under strong stirring. The aqueous $\mathrm{Co}^{2+}$ solution was prepared from $\mathrm{Co}\left(\mathrm{NO}_{3}\right)_{2} \cdot 6 \mathrm{H}_{2} \mathrm{O}$ (Aldrich, $98 \%$ ). The $2 \mathrm{M} \mathrm{NH}_{4} \mathrm{OH}$ aqueous solution was added until the solution was basic $(\mathrm{pH}>10)$ as measured by $\mathrm{pH}$ paper. The $\alpha-\mathrm{Co}(\mathrm{OH})_{2}$ was isolated by vacuum filtration, washed with deionized water several times, and allowed to dry at $85^{\circ} \mathrm{C}$ in a drying oven for a minimum of $12 \mathrm{~h}$. Dark brown $\mathrm{CoOOH}$ was obtained by placing the $\alpha-\mathrm{Co}(\mathrm{OH})_{2}$ under oxygen flow $24 \mathrm{~h}$ (re-grind after $12 \mathrm{~h}$ ) at a temperature of $120{ }^{\circ} \mathrm{C}$. It should be noted that higher temperatures $\left(>130^{\circ} \mathrm{C}\right)$ can result in the formation of $\mathrm{Co}_{3} \mathrm{O}_{4}$, as evidenced by the presence of black powder in the product.

NiOOH. ${ }^{5}$ First, crystalline $\alpha-\mathrm{Ni}(\mathrm{OH})_{2}$ was prepared by precipitation from a $1.0 \mathrm{M} \mathrm{Ni}^{2+}$ aqueous solution with an approximately $2 \mathrm{M} \mathrm{NH}_{4} \mathrm{OH}$ aqueous solution. The aqueous $\mathrm{Ni}^{2+}$ solution was prepared from $\mathrm{NiCl}_{2} \cdot 6 \mathrm{H}_{2} \mathrm{O}$ (Aldrich, $99 \%$ ). The $2 \mathrm{M} \mathrm{NH}_{4} \mathrm{OH}$ aqueous solution was added until the solution was basic $(\mathrm{pH}>10)$ as measured by $\mathrm{pH}$ paper. $\beta-\mathrm{Ni}(\mathrm{OH})_{2}$ was prepared by aging $2 \mathrm{~g}$ of $\alpha-\mathrm{Ni}(\mathrm{OH})_{2}$ in $25 \mathrm{~mL}$ of water under hydrothermal conditions (45 mL Teflon-lined pressure vessel, Parr Instruments) at $125^{\circ} \mathrm{C}$ for $12 \mathrm{~h}$. Finally, $\mathrm{NiOOH}$ was prepared by adding the $2 \mathrm{~g}$ of $\beta-\mathrm{Ni}(\mathrm{OH})_{2}$ in $250 \mathrm{~mL}$ of a diluted $(\sim 4.5 \%) \mathrm{NaClO}$ solution at $55^{\circ} \mathrm{C}$. The dilute $\mathrm{NaClO}$ solution was prepared by adding $95 \mathrm{~mL}$ of commercial $\mathrm{NaClO}$ (Aldrich, available chlorine 10-13\%) with $155 \mathrm{~mL}$ of de-ionized water. The 
$\mathrm{NiOOH}$ was isolated by vacuum filtration, washed with deionized water several times, and allowed to dry in vacuo at ambient temperature.

$\mathbf{G a}_{2} \mathbf{O}_{3}$. Aldrich, $99.995 \%$.

$\mathrm{Y}_{2} \mathbf{O}_{3}$. Alfa Aesar, $99.99 \%$. The $\mathrm{Y}_{2} \mathrm{O}_{3}$ was heated at $850{ }^{\circ} \mathrm{C}$ for 12 hours prior to the reaction.

$\mathbf{R h}_{\mathbf{2}} \mathbf{O}_{3}$. Aldrich, $99.8 \%$.

$\mathbf{R h}(\mathbf{O H})_{3}$. The aqueous $\mathrm{Rh}^{3+}$ solution was prepared by dissolution of $\mathrm{Rh}_{2} \mathrm{O}_{3}$ in a concentrated hydrochloric acid solution. The dissolution rate of $\mathrm{Rh}_{2} \mathrm{O}_{3}$ was increased with mild heating. After cooling, amorphous $\mathrm{Rh}(\mathrm{OH})_{3}$ gel was prepared by precipitation of the cold (ice bath temperature) $\mathrm{Rh}^{3+}$ aqueous solution with excess $2 \mathrm{M} \mathrm{NH}_{4} \mathrm{OH}$. The amorphous $\mathrm{Rh}(\mathrm{OH})_{3}$ was isolated by vacuum filtration, washed with deionized water several times, and allowed to dry at $85{ }^{\circ} \mathrm{C}$ in a drying oven for a minimum of $12 \mathrm{~h}$.

$\mathbf{I n}_{\mathbf{2}} \mathbf{O}_{3}$. Aldrich, $99.999 \%$.

$\operatorname{In}(\mathbf{O H})_{3}$. Crystalline $\mathrm{In}(\mathrm{OH})_{3}$ was prepared by aging $\mathrm{In}_{2} \mathrm{O}_{3}$ in $25 \mathrm{~mL}$ of a $5 \mathrm{M} \mathrm{NaOH}$ solution (Aldrich, $99.999 \%$ ) under hydrothermal conditions (45 mL Teflon-lined pressure vessel, Parr Instruments) for $18 \mathrm{~h}$. The crystalline $\operatorname{In}(\mathrm{OH})_{3}$ was isolated by vacuum filtration, washed with deionized water several times, and allowed to dry at $85^{\circ} \mathrm{C}$ in a drying oven for a minimum of $12 \mathrm{~h}$.

$\mathrm{La}_{2} \mathbf{O}_{3}$. Aldrich, $99.99 \%$. The $\mathrm{La}_{2} \mathrm{O}_{3}$ was heated at $850{ }^{\circ} \mathrm{C}$ for 12 hours prior to the reaction.

$\mathbf{T l}_{\mathbf{2}} \mathbf{O}_{3}$. Alfa Aesar, $99.99 \%$. It should be noted that $\mathrm{Tl}_{2} \mathrm{O}_{3}$ is toxic and should be handled with care. 


\section{References}

(1) Misra, C. Industrial Alumina Chemicals; American Chemical Society: Washington, DC, 1986; American Chemical Society Monograph Series, Vol. 184.

(2) Allen, J. L.; Poeppelmeier, K. R. Polyhedron 1994, 13, 1301-1310.

(3) Schwertmann, U.; Cornell, R. M. Iron Oxides in the Laboratory; 2nd ed; Wiley-VCH: Weinheim, 2000.

(4) Amatucci, G. G.; Tarascon, J. M.; Larcher, D.; Klein, L. C. Solid State Ionics 1996, 84, 169-180.

(5) Palacin, M. R.; Larcher, D.; Audemer, A.; Sac-Epee, N.; Amatucci, G. G.; Tarascon, J. M. J. Electrochem. Soc. 1997, 144, 4226-4236. 